\title{
Detailed Fruit Anatomy of the Genus Grammosciadium DC. (Apiaceae)
}

\author{
Muhammet Ali KARAKAYA $^{1}$, Dudu Özlem MAVİ İDMAN ${ }^{* 2}$, Barış BANi $^{3}{ }^{\mathbb{D}}$ \\ 1,3Kastamonu University, Faculty of Arts and Sciences, Department of Biology, 37200, Kastamonu, Turkey \\ ${ }^{2}$ Republic of Turkey Ministry of Agriculture and Forestry, National Botanical Garden of Turkey, 06800, Ankara, \\ Turkey
}

(Alınıș / Received: 15.02.2021, Kabul / Accepted: 18.05.2021, Online Yayınlanma / Published Online: 15.08.2021)

\author{
Keywords \\ Anatomy, \\ Fruit, \\ Grammosciadium, \\ Apiaceae
}

\begin{abstract}
The genus Grammosciadium is a member of the family Apiaceae and has four taxa namely $G$. daucoides, G. macrodon subsp. macrodon, G. macrodon subsp. nezaketiae and G. cornutum distributed in Turkey. Because the fruit anatomical characters are distinctly important for the taxonomy of the family Apiaceae, this study includes the detailed anatomy of the fruits of the genus. Moreover, some measurements from the fruit anatomy are given. Besides the general anatomy of them, the taxa are evaluated by both qualitative characters such as mericarp types and clarity of ribs and quantitative characters such as number of vascular bundles, number of vittae, size of mericarp, vittae, endosperm and vascular bundles. All the data presented in this research study may be used as a basis for all possible research on the taxonomy of the family and the genu.
\end{abstract}

\section{Grammosciadium DC. (Apiaceae) Cinsinin Detaylı Meyve Anatomisi}

\section{Anahtar Kelimeler}

Anatomi,

Meyve,

Grammosciadium,

Apiaceae

\begin{abstract}
Özet: Grammosciadium cinsi, Apiaceae ailesinin bir üyesidir ve Türkiye'de yayılış gösteren G. daucoides, G. macrodon subsp. macrodon, G. macrodon subsp. nezaketiae ve G. cornutum isimlerinde dört taksonla temsil edilmektedir. Meyve anatomik karakterleri Apiaceae ailesinin taksonomisinde oldukça önemli olduğu için, bu çalışma cinsin detaylı meyve anatomisini içermektedir. Ayrıca, çalışmada meyve anatomisinden bazı ölçümler de verilmiştir. Meyvelerin genel anatomilerinin yanısıra, taksonlar hem merikarp tipi ve rib belirginliği gibi kalitatif karakterler ve hem de iletim demetleri sayısı, vitta sayısı, merikarp, vitta, endosperm ve iletim demeti boyutları gibi kantitatif karakterler ile değerlendirilmiştir. $\mathrm{Bu}$ araştırma çalışmasında ortaya konan tüm veriler, familyanın ve cinsin taksonomisi ile ilgili yapılabilecek tüm araştırmalara temel oluşturabilecek niteliktedir.
\end{abstract}

\section{Giriş}

The anatomical characters of the genus Grammosciadium DC. were firstly discussed by Townsend [1], Tamamschian, and Vinogradova [2] who indicated the importance of fruit anatomy. There are also several current studies that explain the differences in the Apiaceae fruit anatomy [3-9]. For example, Ghahremaninejad et al. [10] studied 14 Iranian species of the genus Bupleurum L. and separate them into two groups according to the absence or presence of vallecular vittae in their fruits. In another study, Yllmaz et al. [11] show the importance of the presence of secretory ducts in the wings of the genus Heptaptera Marg. \& Reuter. Moreover, according to Lee et al. [12], rib numbers and the shape of mericarp are diagnostic for the tribe
Selineae. Also, Zakharova et al. [8] studied with three taxa, one of which is Carum piovanii and they proposed a new combination as Afroligusticum piovanii because of some carpological similarities. In another study, Bani et al. [13] indicated detailed morphological and anatomical characters of genus Grammosciadium and made some taxonomical regulations by using statistical applications with these characters. Moreover, Zakharova et al. [14], used also fruit anatomy to support the molecular investigations to clarify the taxonomy of the genus Hellenocarum H.Wolff.

The genus Grammosciadium is a member of the family Apiaceae and has four taxa namely $G$. daucoides DC., G. macrodon Boiss. subsp. macrodon, $G$. macrodon Boiss. subsp. nezaketiae B.Bani and $G$. 
cornutum (Nábělek) C.C.Towns. distributed in Turkey [15]. Based on the importance of the distinctive property of fruit anatomical characters in the Apiaceae family, detailed fruit anatomy of these 4 taxa belonging to the genus Grammosciadium is given in this study. Also, the characters that may be diagnostic have been identified.

\section{Material and Method}

The materials in Table 1, used for anatomical studies, were gathered from the taxa collected in 22 different localities [16]. All the fruits were sectioned from their middle part by modified Paraffin Sectioning Method [17] using Thermo Shandon Finesse325 microtome. The slices were dyed by applying safranin and fast green [18]. Images were obtained with a Leica
DFC295 camera attached to a Leica DM3000 microscope. The measurements given in Table 2, were performed from 10 different slices of three different fruits, and the average values were calculated from a minimum of 30 values for each character. The terminology for the characters has been written by using previous studies $[2,19,20]$. In this study, some data from a previous master's thesis were used [21].

\section{Results}

\subsection{Grammosciadium daucoides}

In the cross-section of the fruits, a thin cuticle at the outermost and just below single-layered epidermis cells are established. There are 5 primary vascular

Table 1. Taxon Locality, collection date and collection number [16]

\begin{tabular}{|c|c|}
\hline G. daucoides & B7 Erzincan: 1357 m, 04 June 2012, B.B.6816 \\
\hline & A9 Kars: 2050 m, 05 June 2012, B.B.6821 \\
\hline & B9 Muș: 1580 m, 09 June 2012, B.B.6826 \\
\hline & B9 Ağrı: 1650 m, 04 July 2012, B.B.6871 \\
\hline & A8 Bayburt: 2380 m, 04 July 2012, B.B.6876 \\
\hline & A8 Bayburt: 1870 m, 05 July 2012, B.B.6877 \\
\hline & C6 Kahramanmaraș: 1500 m, 19 May 2014, B.B.6959 \\
\hline & B6 Sivas: 1700 m, 21 May 2014, B.B.6963 \\
\hline & C4 Konya: 1500 m, 22 May 2014, B.B.6964 \\
\hline & B7 Tunceli: 1250 m, 13 June 2014, B.B.6978 \\
\hline & B6 Sivas: 1926 m, 02 July 2014, B.B.6984 \\
\hline & B9 Bitlis: 2263 m, 09 July 2014, B.B.6998 \\
\hline G. macrodon subsp. macrodon & C7 Adıyaman: 1250 m, 02 May 2013, B.B. 6908 \\
\hline & B9 Diyarbakır: 1240 m, 06 May 2013, B.B.6917 \\
\hline & B7 Elazığ: 1345 m, 03 May 2013, B.B.6915 \\
\hline & C6 Kahramanmaraş: 2000 m, 19 May 2014, B.B.6958 \\
\hline & B8 Bingöl: 1600 m, 09 July 2014, B.B.7000 \\
\hline G. macrodon subsp. nezaketiae & B9 Bitlis: 1350 m, 13 June 2012, B.B.6844 \\
\hline & B9 Van: 2300 m, 09 July 2014, B.B.6995 \\
\hline & B9 Van: 2000 m, 10 June 2012, B.B.6837 \\
\hline & B9 Van: 1450 m, 10 June 2012, B.B.6832 \\
\hline G. cornutum & B10 Hakkari: 2200 m, 20 June 2012, B.B.6857 \\
\hline
\end{tabular}

Table 2. Fruit measurements of the taxa ( $\mathrm{mm})$

\begin{tabular}{lcccc}
\hline Characters & G. daucoides & $\begin{array}{c}\text { G. macrodon } \\
\text { subsp. macrodon }\end{array}$ & $\begin{array}{c}\text { G. macrodon } \\
\text { subsp. nezaketiae }\end{array}$ & G. cornutum \\
\hline Mericarp length & $1.05 \pm 0.187$ & $0.98 \pm 0.420$ & $1.60 \pm 0.525$ & $1.55 \pm 0.032$ \\
Mericarp width (Commissure area) & $1.62 \pm 0.356$ & $1.68 \pm 0.740$ & $1.72 \pm 0.254$ & $2.33 \pm 0.013$ \\
Mericarp length/width ratio & 0.6 & 0.5 & 0.9 & 0.6 \\
Commissure length & $0.14 \pm 0.051$ & $0.13 \pm 0.039$ & $0.20 \pm 0.196$ & $0.14 \pm 0.027$ \\
Endosperm width & $1.08 \pm 0.352$ & $1.12 \pm 0.416$ & $1.03 \pm 0.295$ & $1.63 \pm 0.017$ \\
Endosperm length & $0.68 \pm 0.155$ & $0.65 \pm 0.259$ & $0.68 \pm 0.131$ & $0.88 \pm 0.051$ \\
Integument thickness & $0.03 \pm 0.010$ & $0.02 \pm 0.013$ & $0.03 \pm 0.009$ & $0.02 \pm 0.004$ \\
Number of vascular bundles & 5 & 5 & 5 & 9 \\
Distance between dorsal vittae & $0.59 \pm 0.129$ & $0.55 \pm 0.165$ & $0.59 \pm 0.076$ & $0.25 \pm 0.005$ \\
Distance between primary bundles & $0.42 \pm 0.122$ & $0.92 \pm 0.067$ & $0.11 \pm 0.093$ & $0.91 \pm 0.063$ \\
Dorsal vittae (oil duct) length & $0.03 \pm 0.010$ & $0.06 \pm 0.043$ & $0.05 \pm 0.084$ & $0.04 \pm 0.009$ \\
Dorsal vittae (oil duct) width & $0.02 \pm 0.008$ & $0.03 \pm 0.021$ & $0.03 \pm 0.008$ & $0.02 \pm 0.005$ \\
Vallecular vittae length & $0.03 \pm 0.140$ & $0.03 \pm 0.013$ & $0.03 \pm 0.015$ & $0.02 \pm 0.004$ \\
Vallecular vittae width & $0.18 \pm 0.072$ & $0.04 \pm 0.016$ & $0.05 \pm 0.024$ & $0.09 \pm 0.015$ \\
Vallecula length (with vittae) & $0.17 \pm 0.033$ & $0.21 \pm 0.082$ & $0.29 \pm 0.110$ & $0.11 \pm 0.021$ \\
Dorsal bundle width & $0.15 \pm 0.034$ & $0.38 \pm 0.134$ & $0.43 \pm 0.056$ & $0.27 \pm 0.011$ \\
Dorsal bundle length & $0.09 \pm 0.025$ & $0.06 \pm 0.015$ & $0.09 \pm 0.016$ & $0.16 \pm 0.012$ \\
Lateral bundle length & $0.14 \pm 0.026$ & $0.29 \pm 0.090$ & $0.38 \pm 0.090$ & $0.29 \pm 0.009$ \\
Lateral bundle width & $0.10 \pm 0.018$ & $0.06 \pm 0.022$ & $0.84 \pm 0.011$ & $0.16 \pm 0.013$ \\
\hline
\end{tabular}




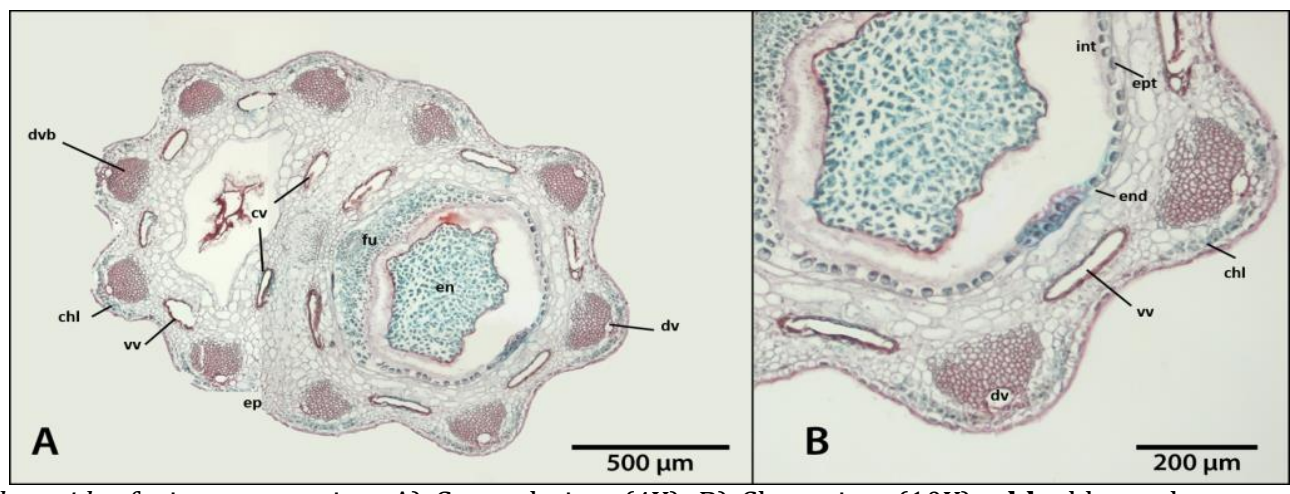

Figure 1. G. daucoides fruit cross section. A) General view (4X), B) Close view (10X); chl: chlorenchyma, cv: commissural vittae, dv: dorsal vittae, dvb: dorsal vascular bundle, en: endosperm, end: endepidermis, ep: epidermis, ept: epitegma, fu: funiculus, int: integument, vv: vallecular vittae

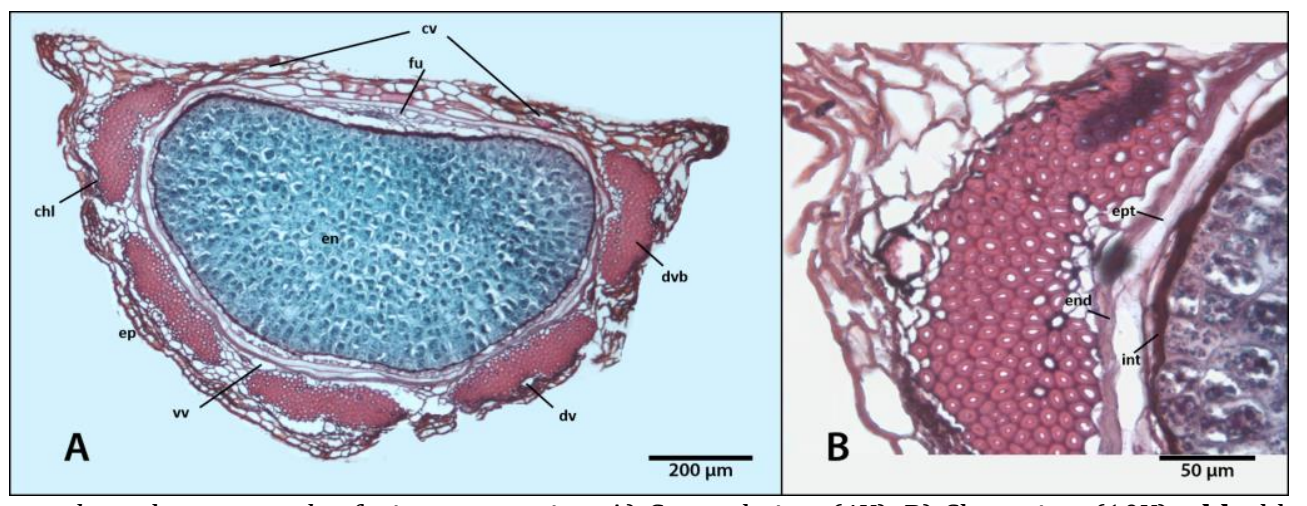

Figure 2. G. macrodon subsp. macrodon fruit cross section. A) General view (4X), B) Close view (10X); chl: chlorenchyma, cv: commissural vittae, dv: dorsal vittae, dvb: dorsal vascular bundle, en: endosperm, end: endepidermis, ep: epidermis, ept: epitegma, fu: funiculus, int: integument, vv: vallecular vittae

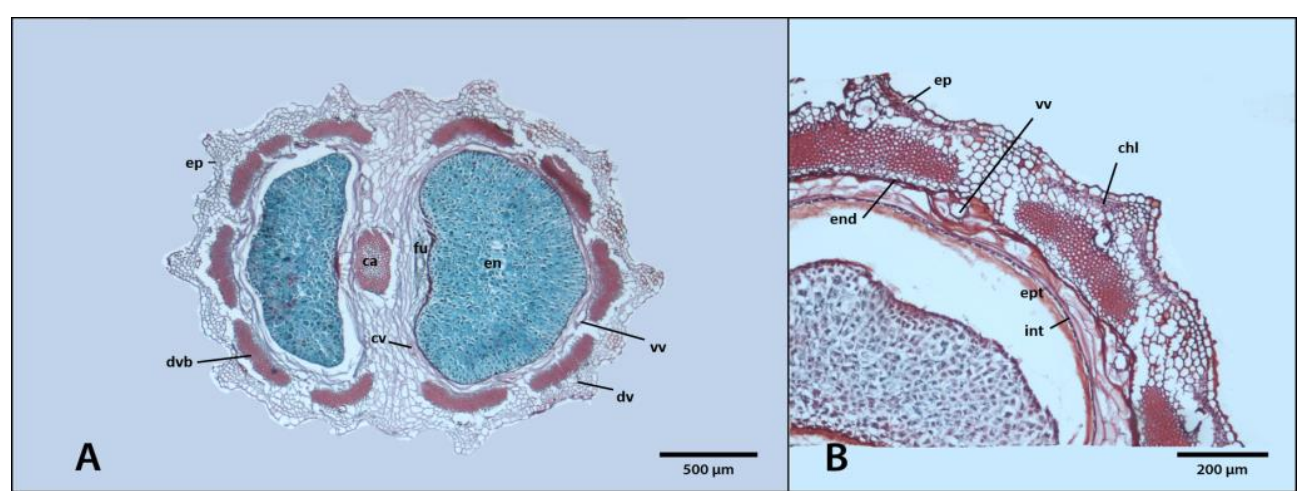

Figure 3. G. macrodon subsp. nezaketiae fruit cross section. A) General view (4X), B) Close view (10X); ca: carpophore, chl: chlorenchyma, cv: commissural vittae, dv: dorsal vittae, dvb: dorsal vascular bundle, en: endosperm, end: endepidermis, ep: epidermis, ept: epitegma, fu: funiculus, int: fragmented integument, vv: vallecular vittae

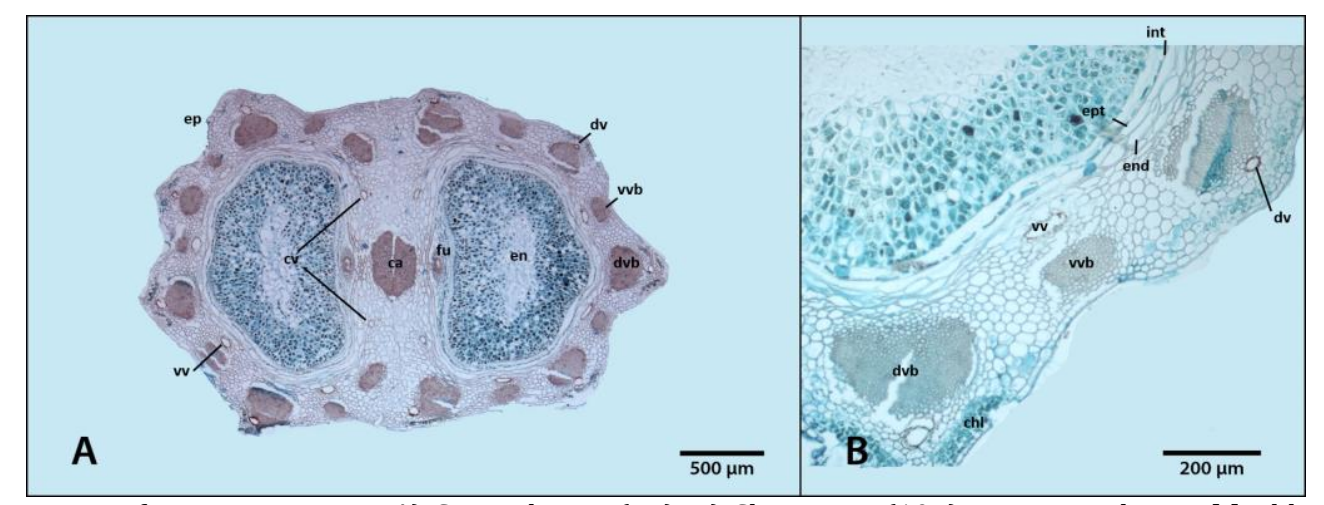

Figure 4. G. cornutum fruit cross section. A) General view (4X), B) Close view (10X); ca: carpophore, chl: chlorenchyma, cv: commissural vittae, dv: dorsal vittae, dvb: dorsal vascular bundle, en: endosperm, end: endepidermis, ep: epidermis, ept: epitegma, fu: funiculus, int: fragmented integument, vv: vallecular vittae, vvb: vallecular vascular bundle 
bundles, making ribs, in a single mericarp, 3 of which are dorsal and 2 of which are lateral (Figure 1.). There is one orbicular rib oil duct (named as dorsal vittae) on each of the bundles and a large, elliptical vallecular vitta between the bundles. Also, there are 2 elliptical-shaped, wide commissural vittae. The pericarp ends with a single row of endepidermis cells innermost. Around the endosperm, there is an epitegma and a fragmented integument.

\subsection{Grammosciadium macrodon subsp. macrodon}

In the cross-section of the fruits, the outermost layer is a thin cuticle and below this cuticle a single layered epidermis is observed (Figure 2.). In one mericarp, 3 dorsal and 2 lateral vascular bundles have formed inconspicuous ribs. There is one rib orbicular oil duct in the upper part of the vascular bundles. There are 2 commissural vittae and 4 vallecular vittae in each mericarp of the fruit. The pericarp layer ends with a single row of endepidermis cells innermost. At the outermost part of the seed attached to the pericarp and the epitegma and the fragmented integument layer surround the endosperm as mentioned in Tamamschian and Vinogradova [2].

\subsection{Grammosciadium macrodon subsp. nezaketiae}

In the cross-section of the fruits, below a thick cuticle at the outermost layer, there is a single layer of epidermis cells is seen. There are 5 primary vascular bundles, 3 of which are dorsal and 2 of which are lateral, that have formed obvious ribs in the pericarp (Figure 3). In the upper part of each bundle, towards the epidermis, there is one orbicular oil duct and there are several layers of chlorenchyma and parenchyma between this vitta and the epidermis. The vallecula has a multilayered crushed ellipticalshaped vitta close to the endepidermis. The pericarp ends with a single-layered endepidermis cells innermost. Epitegma and fragmented integument layers surround the endosperm on the outermost part of the seed attached to the pericarp. In addition, there are 2 commissural vittae close to the lateral bundles.

\subsection{Grammosciadium cornutum}

In the cross-sections of the fruits, the cuticle surrounds the single-layered epidermis cells. There are 9 primary vascular bundles in the pericarp, 3 of which are dorsal, 2 are lateral, and 4 are vallecular. There are 1 orbicular rib oil duct in the upper part of each dorsal and lateral bundle and a few layers of chlorenchyma and parenchyma tissue over these vittae protrudes outward (Figure 4). There are also vallecular vittae under the vallecular bundles, independently of each other. The pericarp layer ends with a single layer of endepidermis cells innermost. Epitegma and fragmented integument layer surround the endosperm. In addition, there are 2 commissural vittae.

\section{Discussion and Conclusion}

Because of the presence of the vallecular vascular bundles, the mericarps of $G$. cornutum have 9 vascular bundles. However, the other taxa have 5 vascular bundles in their mericarps. Moreover, fruit primary ridges are generally prominent. However, $G$. macrodon subsp. macrodon seems to have obscure primary ridges. Tuncay and Yeşil [22] studied the fruit anatomy of $G$. daucoides and mentioned that there are 4 vallecular and 2 commissural vittae in its mericarps. Although not as distinct as in G. daucoides mericarp, there are 4 vallecular and 2 commissural vittae in the mericarps of all the taxa. Also, $G$. daucoides has the widest vallecular vittae, measured as $0.18 \pm 0.072 \mathrm{~mm}$. According to Zakharova et al. [8], morphological similarity including the obtuse-keeled ribs and winged-marginal ribs can be used as a diagnostic character. From this point of view, in the mericarps of $G$. macrodon subsp. macrodon the primary ribs seem to be inconspicuous. However, the other taxa have prominent primary ribs in their mericarps. On the other hand, subsp. macrodon only has prominent marginal ribs. Bani et al. [23] distinguished G. macrodon subsp. nezaketiae from the other taxa, with its tuberculate-striate type of fruit surface. It is also seen from the anatomical slices that, G. macrodon subsp. nezaketiae has wing-like small striate on the dorsal side primary ribs.

Wojewódzka et al. [24] used several quantitative characters such as mericarp length to width ratio, and dorsal bundle thickness to width ratio to show the evolutionary shift in tribe Scandiceae of the family. Also, there are many measurements made in this study that is similar to the previous study. In this research, measurements gathered from the fruits, shown in Table 2. According to these measurements, the fruits of $G$. cornutum have the widest mericarp measured from the commissure area. Also, the length of the dorsal bundle and the size of the endosperm have the highest values. However, in some measurements such as distance between dorsal vittae, length of vallecula the species has the smallest values (Table 2). Moreover, in the fruits of $G$. macrodon subsp. nezaketiae the distance between two primary bundles has the shortest value. On the other hand, the fruits of the taxon have the highest values within the measurements as the width of dorsal and lateral bundles and length of commissure and vallecular area. These findings support the previous studies that justified the large vascular bundles of the fruits of $G$. macrodon subsp. nezaketiae $[15,25]$.

In conclusion, the general anatomy of taxa has 4 vallecular and 2 commissural vittae. However, there are differences between the measurements of these that, $G$. daucoides has the widest vallecular vittae. Moreover, only $G$. cornutum has 9 vascular bundles and the other taxa have 5 vascular bundles. And $G$. 
macrodon subsp. nezaketiae has the widest vascular bundles located both dorsally and laterally. Also, all the taxa have prominent primary ribs, while $G$. macrodon subsp. macrodon has just marginal prominent ribs.

\section{Acknowledgment}

We wish to thank the Scientific and Technological Research Council of Turkey (TUBITAK-114Z094) for their financial support.

\section{Declaration of Ethical Code}

In this study, we undertake that all the rules required to be followed within the scope of the "Higher Education Institutions Scientific Research and Publication Ethics Directive" are complied with, and that none of the actions stated under the heading "Actions Against Scientific Research and Publication Ethics" are not carried out.

\section{Kaynakça}

[1] Townsend, C. C. 1966. Notes on the Umbelliferae of Iraq : III. Kew Bulletin, 20(1), 77-85.

[2] Tamamschian, S. G., Vinogradova, V. M. 1969. A contribution to the taxonomy of the genus Grammosciadium DC. (Umbelliferae). Botanicheskii Zhurnal (Leningrad) 54, 11971212.

[3] Van Wyk, B. E., Tilney, P. M. 1994. The taxonomic value of fruit wall structure in the genus Annesorhiza (Apiaceae). South African Journal of Botany, 60(5), 240-244.

[4] Khajepiri, M., Ghahremaninejad, F., Mozaffarian, V. 2010. Fruit anatomy of the genus Pimpinella L. (Apiaceae) in Iran. Flora, 205, 344-356.

[5] Yembaturova, E. Y., Van Wyk, B. E., Tilney, P. M., Winter, P. J. D. 2010. The taxonomic significance of fruit morphology and anatomy in the genus Alepidea delaroche (Apiaceae, subfamily Saniculoideae). Plant Diversity and Evolution, 128(3-4), 369-385.

[6] Zakharova, E. A., Degtjareva, G. V., Pimenov, M. G. 2012. Redefined generic limits of Carum (Umbelliferae, Apioideae) and new systematic placement of some of its taxa. Willdenowia, 42, 149-168.

[7] Özdemir, E., Kültür, Ș. 2014. Fruit anatomy of some Apiaceae plant species from NiğdeAladağlar/Turkey. Journal of Faculty of Pharmacy of Istanbul University, 44, 215-223.

[8] Zakharova, E. A., Degtjareva, G. V., Kljuykov, E. V., Tilney, P. M. 2014. The taxonomic affinity of Carum piovanii Chiov. and some Bunium species (Apiaceae). South African Journal of Botany, 94, 122-128.
[9] Pimenov, M. G., Ostroumova, T. A., Degtjareva, G. V., Samigullin, T. H. 2016. Sillaphyton, a new genus of the Umbelliferae, endemic to the Korean Peninsula. Botanica Pacifica, 5, 31-41.

[10] Ghahremaninejad, F., Hoseini, E., Mozaffarian, V. 2014. Fruit anatomy of the genus Bupleurum L. (Apiaceae) in Iran. Iranian Journal of Botany, 20(1), 51-70.

[11] Yılmaz, G., Kaya, A., Koyuncu, M. 2016. Fruit morphology and anatomy of Heptaptera marg. \& reuter (Apiaceae) species grown in Turkey. Journal of Faculty of Pharmacy of Ankara University, 40(2), 26-42.

[12] Lee, C., Kim, J., Darshetkar, A. M., Choudhary, R. K., Park, S. H., Lee, J., Choi, S. 2018. Mericarp morphology of the tribe Selineae (Apiaceae, Apioideae) and its taxonomic implications in Korea. Bangladesh Journal of Plant Taxon, 25(2), 175-186.

[13] Bani, B., Ulusoy, F., Karakaya, M. A., Koch, M. A. 2016. Taxonomic implications from morphological and anatomical studies in the section Stenodiptera from the genus Grammosciadium (Apiaceae). Phytokeys, 68, 7389.

[14] Zakharova, E. A., Kljuykov, E. V., Degtjareva, G. V., Samigullin, T. H., Ukrainskaya, U. A., Downie, S. R. 2016. A taxonomic study of the genus Hellenocarum H.Wolff (Umbelliferae-Apioideae) based on morphology, fruit anatomy, and molecular data. Turkish Journal of Botany, 40, 176-193.

[15] Koch, M. A., Bani, B., German, D. A., Huang, X. 2017. Phylogenetics, phylogeography and vicariance of polyphyletic Grammosciadium (Apiaceae: Careae) in Anatolia. Botanical Journal of the Linnean Society 185, 168-188.

[16] Ulusoy, F., Karakaya, M. A., Mavi İdman, D. Ö., Bani, B. 2017. A new diagnostic character in the roots of the genus Grammosciadium DC. (Apiaceae). Phytotaxa, 292, 150-160.

[17] Johansen, D. A. 1940. Plant microtechnique. McGraw-Hill, New York- USA, 523s.

[18] Algan, G. 1981. Microtechnics for the plant tissues. Publication of Firat University Science and Art Faculty, İstanbul-Turkey, 94s.

[19] Kljuykov, E. V., Liu, M., Ostroumova, T. A., Pimenov, M. G., Tilney, P. M., Van Wyk, B. E. 2004. Towards a standardised terminology for taxonomically important morphological characters in the Umbelliferae. South African Journal of Botany, 70(3), 488-496.

[20] Kızılarslan-Hançer, Ç.., Akalın-Uruşak, E. 2017. Apiaceae familyası meyve anatomisindeki "Vitta" terimi ve yerleşimleri. Avrasya Terim Dergisi, 5(2), 19-24. 
[21] Karakaya, M. A. 2018. Türkiye'de yayılış gösteren Grammosciadium DC. (Apiaceae) cinsine ait taksonların anatomik özellikleri. Kastamonu Üniversitesi, Fen Bilimleri Enstitüsü, Yüksek Lisans Tezi, 70s, Kastamonu.

[22] Tuncay, H. O., Yeşil, Y. 2019. Comparative fruit anatomy and morphology of four species known as cumin (Kimyon) in Turkey. Kahramanmaraş Sütçü İmam Üniversitesi Journal of Agriculture and Nature, 22(4), 547-556.

[23] Bani, B., Karakaya, M. A., Çeter, T. 2016. Fruit micromorphological characters of the genus
Grammosciadium DC. (Apiaceae) in Turkey. Phytotaxa, 246, 184-191.

[24] Wojewódzka, A., Baczyński, J., Banasiak, L., Downie, S. R., Czarnocka-Cieciura, A., Gierek, M., Frankiewicz, K., Spalik, K. 2019. Evolutionary shifts in fruit dispersal syndromes in Apiaceae tribe Scandiceae. Plant Systematics and Evolution, 305, 401-414.

[25] Bani, B., Koch, M. A. 2015. A new subspecies of Grammosciadium macrodon Boiss. (Apiaceae) from Turkey, Phytotaxa, 224, 267-275. 